УДК 616.071-001.3/6-06:612.34-008.87]-092.9

$\mathrm{DOI}$

(С) Р. Д. ЛЕВЧУК

ДВНЗ “Тернопільський державний медичний університет імені І. Я. Горбачевського”

\title{
Роль порушення всмоктувальної функції тонкої кишки в патогенезі раннього періоду скелетної, черепно-мозкової та поєднаної травм
}

\author{
R. D. LEVCHUK \\ SHEI "Ternopil State Medical University by I. Ya. Horbachevsky"
}
ROLE ABUSE FUNCTION OF ABSORPTION OF THE SMALL INTESTINE IN THE PATHOGENESIS OF THE EARLY PERIOD OF SKELETAL, CRANIOGEREBRAL AND COMBINED GRANIO SCELETAL INJURIES

\begin{abstract}
У статті вивчено особливості всмоктувальної функції тонкої кишки за тестом із D-ксилозою в ранній період (1-7 доби) після моделювання скелетної, черепно-мозкової та поєднаної краніоскелетної травм. Встановлено, що нанесення різних за локалізацією механічних травм супроводжується порушенням всмоктувальної функції тонкої кишки, проявляється суттєвим зниженням вмісту D-ксилози в сечі, залежить від тяжкості пошкоджень і є більшим на тлі поєднаної краніоскелетної травми через 1-3 доби посттравматичного періоду. Тривалість розладів всмоктувальної функції після самої скелетної і черепно-мозкової травм нормалізується через 7 діб, що вказує на високі функціональні резерви тонкої кишки. Після поєднаної травми в цей термін всмоктувальна функція тонкої кишки істотно покращується, проте не досягає рівня контролю. Отримані результати націлюють на можливість раннього ентерального харчування після 3-ї доби посттравматичного періоду, що потребує подальшого вивчення.

The article investigated the function of absorption of the small intestine by a test of D-xylose in the early period (1-7 days) after skeletal modeling, craniocerebral and combined cranio sceletal injuries. It was Found out that applying different localized mechanical traumas is accompanied by abuse function of absorption of the small intestine, is manifested by significant reduction of $\mathrm{D}$-xylose in urine and depends on the severity of damage. The most pronounced decrease is observed against the background of combined cranio sceletal injury after 1-3 days of the post-traumatic period. Continuance of abuse function of absorption of the small intestine after the skeletal and craniocerebral injuries is normalized after $\mathbf{7}$ days, that points to high functional reserves of the small intestine. After combined injury the function of absorption of the small intestine is significantly improves, but does not reach the level of control. These results are directed towards the possibility of early enteral feeding after 3 days of post-traumatic period that requires further study.
\end{abstract}

Постановка проблеми і аналіз останніх досліджень та публікацій. Черепно-мозкова травма, особливо в поєднанні із пошкодженням кісток скелета, належить до однієї із важливих проблем охорони здоров’я і провідних причин смертності та інвалідності в розвинених країнах. У загальній структурі травм питома вага поєднаних і множинних уражень щорічно зростає, зумовлюючи летальність від 15 до 40 \%, інвалідність - від 25 до $45 \%$, та займає третє місце серед причин загибелі організму [9].

Як свідчать дані літератури, пік летальності в умовах поєднаної краніоскелетної травми настає 33 до 24 год посттравматичного періоду та з 3-ї до 7-ї доби [3]. Якщо перший період пов'язаний із тяжкістю пошкоджень та травматичним шоком, то другий - із розвитком поліорганної недостатності [2]. Провідна роль у її патогенезі належить шлунково-кишковому тракту, в якому виникають порушення внаслідок централізації гемодинаміки, розладів мікроциркуляції в кишковій стінці, гіпоксичного та реперфузійного ушкодження ентероцитів, дії прозапальних медіаторів, набряку кишкової стінки $[4,5]$. В цих умовах виникає синдром ентеральної недостатності, який проявляється порушенням моторно-евакуаторної, бар’єрної, секреторної та всмоктувальної функцій кишок, а також пристінкового і внутрішньопросвітного травлення [1]. Завдяки транслокації мікрофлори і масовому надходженню у кровотік мікробного токсину - ліпополісахариду замикається чергове “хибне” патологічне коло, яке запускає каскад реакцій, що прискорює розвиток поліорганної недостатності. 
Однак закономірності формування синдрому ентеральної недостатності в ранній період краніоскелетної травми вивчені недостатньо. Немає даних про особливості всмоктувальної функції тонкої кишки на тлі експериментальної скелетної, черепно-мозкової та поєднаної травм.

Мета роботи: з'ясувати роль порушення всмоктувальної функції тонкої кишки в патогенезі раннього періоду після моделювання скелетної, черепномозкової та поєднаної травм.

Матеріали і методи. Експерименти виконано на 104 нелінійних білих щурах масою 180-200 г, яких утримували на стандартному раціоні віварію. Нанесення травм виконували в умовах тіопенталонатрієвого наркозу (40 мг·кГ-1 маси). Моделювання поєднаної краніоскелетної травми виконували за розробленою нами методикою шляхом дозованого удару по обох задніх лапах за допомогою спеціально розробленого пристрою, який викликав закритий перелом обох стегон, та нанесення дозованого удару по черепу з енергією 0,375 Дж, що відповідало травмі середнього ступеня тяжкості [8]. В окремих групах ці травми наносили окремо. Контрольну групу склали інтактні тварини.

У тварин, які вижили, через 1, 3 і 7 діб посттравматичного періоду вивчали всмоктувальну функцію кишок за D-ксилозним тестом. D-ксилоза $є$ хімічно інертним вуглеводом, який абсорбується шляхом пасивної дифузії, не метаболізується в організмі людини, виводиться із сечею і досить адекватно відображає всмоктувальну функцію тонкої кишки [7]. Піддослідним тваринам внутрішньошлунково вводили $10 \%$ розчин D-ксилози із розрахунку 100 мг кг $^{-1}$ маси тіла. Далі у тварин протягом 4 год збирали сечу, в якій визначали концентрацію D-ксилози [10]. 3 експерименту тварин виводили в умовах знеболювання методом тотального кровопускання з серця.

Для достовірності відмінностей між експериментальними групами статистичну обробку ре- зультатів виконано у відділі системних статистичних досліджень університету в програмному пакеті StatSoft STATISTICA.

Результати досліджень та їх обговорення. Як видно з таблиці 1 і рисунка 1, вміст D-ксилози у сечі під впливом скелетної травми порівняно із контрольною групою через 1 і 3 доби посттравматичного періоду статистично вірогідно зменшувався (відповідно, на 23,7 і 34,9 \%, p<0,05). Проте через 7 діб повертався до рівня контрольної групи $(\mathrm{p}>0,05)$, що виявилося істотно більшим, ніж через 3 доби після нанесення травми (на 27,6 \%, $\mathrm{p}<0,05)$.

Після моделювання черепно-мозкової травми порівняно 3 контрольною групою показник теж зменшувався, проте тільки через 3 доби результат виявився статистично значущим (на 22,9 \%, $\mathrm{p}<0,05)$. Через 7 діб його величина поверталася до рівня контролю ( $>0,05)$.

Після нанесення поєднаної травми у всі терміни спостереження вміст D-ксилози у сечі виявився істотно меншим, ніж у контрольній групі: через 1 добу - на 40,6 \%, через 3 доби - на 56,5 \%, через 7 діб - на 26,6 \% (p<0,05).

Порівнюючи дослідні групи між собою, з'ясувалося, що через 1 добу вміст D-ксилози в сечі був суттєво меншим після поєднаної травми порівняно із самими скелетною і черепно-мозковою травмами (відповідно, на 22,2 \%, $\mathrm{p}_{1-3}<0,05$ і 33,5 \%, $\mathrm{p}_{2-3}<0,05$ ). Аналогічну ситуацію відмічали й через 3 доби: відповідно, на 33,2 \% $\left(\mathrm{p}_{1-3}<0,05\right)$ і 43,6 \% $\left(\mathrm{p}_{2-3}<0,05\right)$. Через 7 діб показник був найнижчим після поєднаної травми, далі - самої скелетної і черепно-мозкової, проте результат між дослідними групами виявився статистично не вірогідним ( $>0,05)$.

Таким чином, моделювання різних за локалізацією механічних травм супроводжується порушенням всмоктувальної функції тонкої кишки, що проявляється суттєвим зниженням вмісту D-ксилози у $(\mathrm{M} \pm \mathrm{m})$

Таблиця 1. Вміст D-ксилози (мг·мл ${ }^{-1}$ ) у сечі в динаміці скелетної, черепно-мозкової та поєднаної травм

\begin{tabular}{||l|c|c||c|c||}
\hline \multicolumn{1}{|c|}{ Вид травми } & Контроль & 1-ша доба & 3-тя доба & 7-ма доба \\
\hline скелетна & \multirow{3}{*}{$53,93 \pm 4,71$} & $41,16 \pm 3,22^{*}(\mathrm{n}=6)$ & $35,12 \pm 1,91^{*}(\mathrm{n}=6)$ & $44,82 \pm 2,64(\mathrm{n}=6)$ \\
\cline { 1 - 3 } черепно-мозкова & $48,20 \pm 2,98(\mathrm{n}=6)$ & $41,58 \pm 2,25^{*}(\mathrm{n}=6)$ & $47,20 \pm 2,66(\mathrm{n}=6)$ \\
\cline { 1 - 3 } & & $32,03 \pm 2,02^{*}(\mathrm{n}=6)$ & $23,47 \pm 1,97^{*}(\mathrm{n}=6)$ & $39,57 \pm 2,32^{*}(\mathrm{n}=6)$ \\
\hline $\mathrm{p}_{1-2}$ & $>0,05$ & $>0,05$ & $>0,05$ \\
\hline $\mathrm{P}_{1-3}$ & $<0,05$ & $<0,05$ & $>0,05$ \\
\hline $\mathrm{P}_{2-3}$ & $<0,05$ & $<0,05$ & $>0,05$ \\
\hline \hline
\end{tabular}

Примітки: ${ }^{*}$ - відмінності стосовно контрольної групи статистично вірогідні $\left.{ }^{*}-\mathrm{p}<0,05\right) ; \mathrm{p}_{1-2}-$ вірогідність відмінностей між дослідними групами із скелетною та черепно-мозковою травмою; $\mathrm{p}_{1-3}-$ вірогідність відмінностей між дослідними групами із скелетною та поєднаною травмою; $\mathrm{p}_{2-3}$ - вірогідність відмінностей між дослідними групами із черепно-мозковою та поєднаною травмою. 


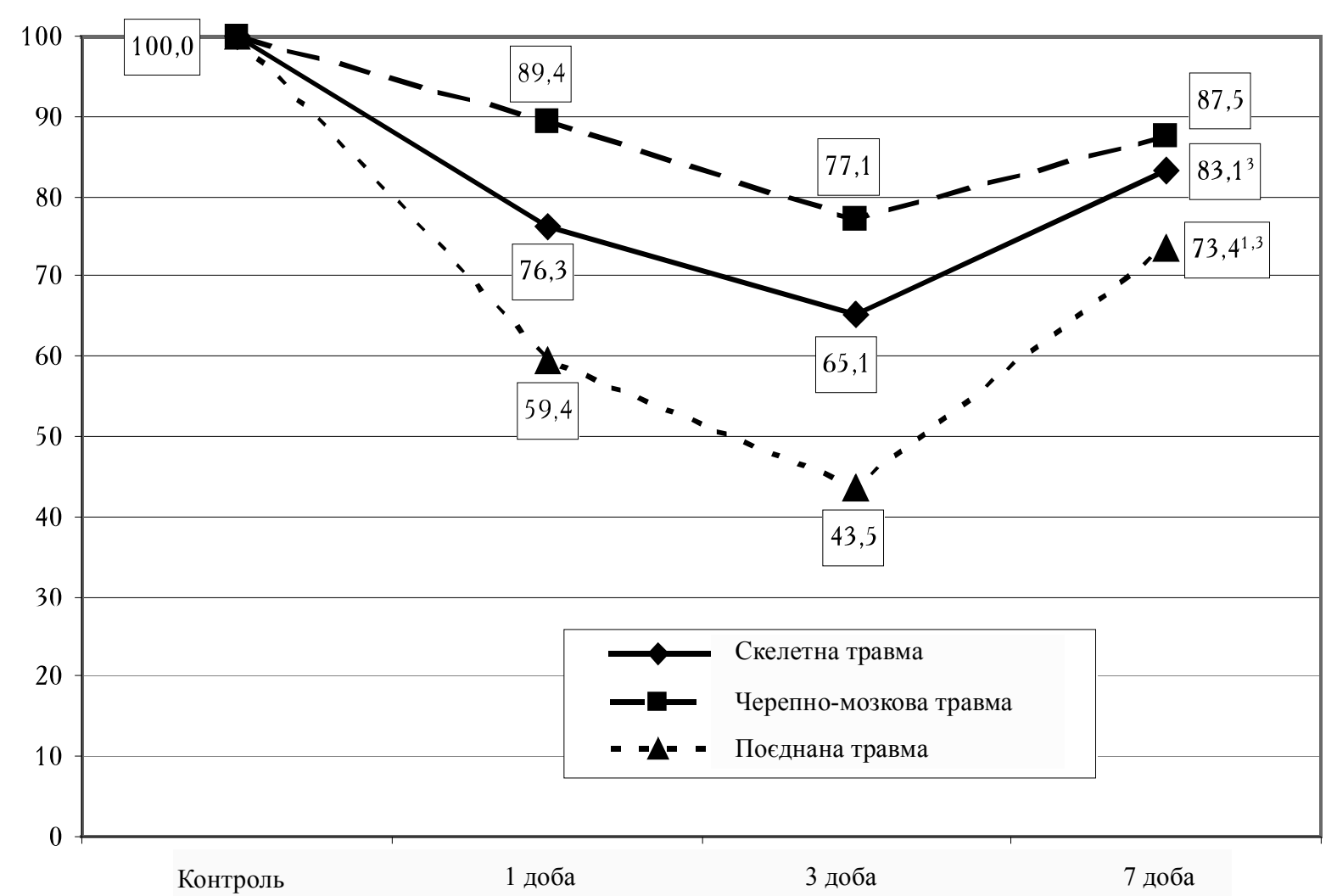

Рис. 1. Динаміка вмісту D-ксилози в сечі (у відсотках до рівня контролю) після скелетної, черепно-мозкової та поєднаної травм (1,3 - відмінності, відповідно, порівняно із 1-ю і 3-ю добою статистично вірогідні, p<0,05).

сечі і найбільш виражено після поєднаної травми через 1 і 3 доби посттравматичного періоду.

Отже, вираження порушень всмоктувальної функції тонкої кишки на тлі механічної травми без пошкодження органів черевної порожнини залежить від тяжкості пошкоджень і є більшим на тлі поєднаної краніоскелетної травми через 1-3 доби посттравматичного періоду. Тривалість розладів всмоктувальної функції після самої скелетної і черепно-мозкової травм нормалізується через 7 діб, що вказує на високі функціональні резерви тонкої кишки. Після поєднаної травми в цей термін всмоктувальна функція тонкої кишки істотно покращується, проте не досягає рівня контролю. В основі виявлених порушень лежить, очевидно, неспецифічна реакція органів спланхнічної зони на централізацію кровообігу та генералізовану іше- мію. На це вказують результати наших попередніх досліджень, в яких було показано суттєве переважання прооксидантних механізмів у стінці тонкої кишки у відповідь на модельовані травми з явним переважанням порушень в умовах поєднаної краніоскелетної травми [6]. Отримані результати націлюють на можливість раннього ентерального харчування після 3-ї доби посттравматичного періоду, що потребує подальшого вивчення.

Висновок. Моделювання скелетної, черепномозкової і поєднаної краніоскелетної травм супроводжується порушенням всмоктувальної функції тонкої кишки, що проявляється суттєвим зниженням вмісту D-ксилози у сечі i найбільш виражено після поєднаної травми через 1 i 3 доби посттравматичного періоду.

\section{СПИСОК ЛІТЕРАТУРИ}

1. Андрющенко В. П. Синдром ентеральної недостатності при гострому панкреатиті: патоморфологічні зміни слизової оболонки тонкої кишки та шляхи їх медикаментозної корекції / В. П. Андрющенко, В. В. Куновський, В. А. Мальований // Харківська хірургічна школа. - 2008. - № 2 (29). - С. 72-75. 2. Дужий І. Д. Особливості лікувально-діагностичної тактики при поєднаній краніоабдомінальній травмі / І. Д. Ду-

жий, В. П. Шевченко, В. В. Шевченко // Актуальні проблеми сучасної медицини: Вісник Української медичної стоматологічної академії. - 2009. - Т. 9, В. 1. - С. 214-215.

3. Исходы сочетанной черепно-мозговой и скелетной травмы в г. Ташкенте / А. Турапов, С. С. Рабинович, К. Э. Махкамов [и др.] // Бюллетень сибирской медицины. - 2008. - № 5. C. $177-182$. 
4. Крутько Е. Н. Лечение синдрома энтеральной недостаточности у пострадавших с травматической болезнью / Е. Н. Крутько // Харьковская хирургическая школа. - 2008. №1 (28). - С. 73-75.

5. Левчук Р. Д. Морфологічні порушення тонкої кишки як передумова розвитку ентеральної недостатності в динаміці поєднаної краніоскелетної травми / Р. Д. Левчук, І. М. Дейкало, Т. В. Дацко // Матеріали підсумкової науково-практичної конференції “Здобутки клінічної і експериментальної медицини”, 21 травня 2014 р. - Тернопіль : Укрмедкнига, 2014. - C. 121.

6. Левчук Р. Д. Роль ліпопероксидації та антиоксидантного захисту в патогенезі ураження стінки тонкої кишки в динаміці краніоскелетної травми / Р. Д. Левчук, І. М. Дейкало // Здобутки клінічної і експериментальної медицини. - 2013. № 2. - С. 120-123.
7. Маркина А. И. Влияние энтеросорбентов на всасывание D-ксилозы в кишечнике лабораторных животных: физикохимический аспект / А. И. Маркина, И. И. Геращенко // Поверхность. - 2013. - Вып. 5 (20). - С. 301-307.

8. Пат. 81107 Україна, МПК G 09 В 23/28. Спосіб моделювання політравми / Левчук Р. Д., Михайлюк I. А., Мерлєв Д. І. ; заявник і патентовласник Державний вищий навчальний заклад “Тернопільський державний медичний університет імені I. Я. Горбачевського МОЗ України” . - № u 201213575 ; заявл. 27.11.12; опубл. 25.06.13, Бюл. 12.

9. Epidemiological aspect of traumatic brain injury in Northeast Italy / V. Baldo, A. Marcolongo, A. Floreani [et al.] // Eur. J. Epidemiol. - 2003. - Vol. 18 (11). - P. 1059-1063.

10. Swinnen M. J. A colorimetric micromethod for the estimation of xylose in blood and urine / M. J. Swinnen // Biol. et gastroenterol. - 1968. - № 2. - P. 194-200. 